Article

\title{
Does the EU Have Moral Authority? A Communicative Action Perspective on Sanctions
}

\author{
Giselle Bosse \\ Department of Political Science, Maastricht University, The Netherlands; g.bosse@maastrichtuniversity.nl
}

Submitted: 9 July 2021 | Accepted: 18 October 2021 | Published: 26 January 2022

\begin{abstract}
The European Union (EU) states in its 2016 Global Strategy that it intends to be a "responsible global stakeholder" and to "act worldwide to address the core causes of war and poverty, as well as to promote the indivisibility and universality of human rights" (European Union Global Strategy, 2016, pp. 5-8, 18). However, the Global Strategy is silent on the credentials or prerequisites that give the EU the authority to act globally and address conflicts and violations of human rights, including through the use of sanctions against non-EU states. How far the EU has the authority to use sanctions, which are essentially coercive measures, is especially relevant when the EU resorts to unilateral sanctions based on obligations owed erga omnes, namely measures without explicit United Nations Security Council authorisation and based on obligations owed to the international community as a whole. Drawing on Habermas's theory of communicative action, this article introduces an analytical framework - the "moral dimension" of EU authority-which maps the substantive and procedural standards to guide the assessment of whether the EU has the appropriate credentials to qualify as an authority with the right to intervene forcibly into the internal affairs of non-EU states. The analytical value of the framework is examined empirically in the case study of the EU's restrictive measures (sanctions) imposed in response to state violence against anti-government protests in Uzbekistan in 2005.
\end{abstract}

\section{Keywords}

deliberative legitimacy; European Union; foreign policy; Habermas; sanctions; theory of communicative action

\section{Issue}

This article is part of the issue "Beyond Foreign Policy? EU Sanctions at the Intersection of Development, Trade, and CFSP" edited by Katharina Meissner (University of Vienna) and Clara Portela (University of Valencia).

(C) 2022 by the author(s); licensee Cogitatio (Lisbon, Portugal). This article is licensed under a Creative Commons Attribution 4.0 International License (CC BY).

\section{Introduction}

This article aims to examine how far the European Union (EU) has the authority to resort to unilateral sanctions against non-EU states (third countries) and, if so, based on which standards.

The 2016 Global Strategy for the European Union's Foreign and Security Policy outlines that a "fragile world calls for a more confident and responsible" EU, promising to become a "responsible global stakeholder" and to "act globally to address the root causes of conflict and poverty, and to champion the indivisibility and universality of human rights" (European Union Global Strategy, 2016, pp. 5-8).

The Global Strategy acknowledges the EU's growing international obligations but does not elaborate on the credentials or prerequisites which entitle the EU with the authority to act globally to address conflict and human rights violations, including the use of coercive measures, such as sanctions (restrictive measures). Whether and how far the EU has the authority to impose sanctions are especially relevant questions when the EU resorts to such measures against third countries without explicit United Nations Security Council authorisation. So far, all of the EU's military operations have received prior authorisation by the United Nations Security Council. However, the EU increasingly demonstrates its readiness to act without UN authorisation, especially in pursuit of humanitarian goals. Over the past decades, the EU has resorted to unilateral sanctions against third countries found in violation of international law or guilty of serious human rights violations against their own citizens. 
While sanctions cannot be equated with the use of force, they are considered a "foreign policy instrument closest to the use of force" (Giumelli et al., 2021, p. 5). And, as it lacks its own military force, the EU predominantly uses sanctions to live up to its role as a responsible global stakeholder.

While the EU, as an international organisation (IO), has the power under general international law to adopt countermeasures (sanctions) to react to "international wrongful acts that injure it directly" (Tzanakopoulos, 2015 , p. 148), most EU sanctions have been imposed in response to serious human rights violations in third countries. This is one of the most problematic types of sanctions, since the EU has not been directly injured by an internationally wrongful act, but rather acts in the general interest of the international community. The legality of these sanctions in the general interest remains a matter of significant controversy (Biersteker \& Portela, 2015, p. 2; Sicilianos, 2002; Tams, 2005). In its Global Strategy, the EU has also explicitly committed itself to "promote the responsibility to protect" (European Union Global Strategy, 2016, p. 42), through which the EU (potentially) assumes the right and authority to use coercive measures, such as sanctions, in case of supreme human rights emergencies. In light of these developments, it appears all the more pertinent to enquire into the sources of the EU's authority to resort to unilateral sanctions against third countries.

Therefore, the main question guiding this article is: What are the sources of the EU's authority to resort to unilateral sanctions against non-EU states? And based on which standards may such measures be justified?

To date, only a few scholarly works have engaged with the question of the EU's authority to resort to unilateral coercive measures such as sanctions, and in particular "countermeasures in the general interest" - that is, measures in reaction to violations of obligations erga omnes (obligations owed to the international community as a whole). An enquiry into the EU's authority to use coercive actions against third countries is also relevant in the wider context of ongoing scholarly discussions about the moral responsibilities of states, IOs, and non-state actors to intervene in human rights emergencies when a UN authorisation is prevented due to power politics among the veto players in the Security Council (e.g., Brown, 2004; Erskine, 2004, 2014). In some of these discussions, the EU is often viewed as a likely candidate to assume such responsibilities because societies that are "evolving in post-national and post-sovereign directions may have...the skills that are needed to build tolerant societies elsewhere" and "promoting more humane forms of national and global governance" (Linklater, 2007, p. 78).

The article is structured as follows: In Section 2, the article reviews the literature to examine how far current scholarship has engaged with the EU's authority to resort to unilateral sanctions against third countries and point to a number of research gaps. In Section 3, the article introduces the theoretical framework, the "moral dimension" of EU authority, to analyse the moral and ethical sources of the EU's authority to resort to unilateral sanctions and standards that justify such measures. Drawing on Habermas's theory of communicative action (1987/2006), the framework maps two standards, the substantive commitment to ethical and moral reason and the procedural commitment to discourse ethics, which help to assess whether the EU has the appropriate credentials to qualify it as a moral authority allowing it to unilaterally use coercive actions such as sanctions against sovereign non-EU states. In Section 4, I will assess the analytical value of conceptualising the moral dimension of EU authority in the context of an illustrative case study, probing into the EU's authority with regards to its decision to impose, and subsequent decision not to prolong, the unilateral sanctions against the government of Uzbekistan, in reaction to the massacre of civilians in the Uzbek town of Andijon following anti-government protests in May 2005.

\section{EU Coercive Measures Against Third Countries: State of the Art}

An academic exchange on whether the EU possesses the moral authority to resort to unilateral coercive measures such as sanctions against non-EU states-and, if so, based on which standards-has yet to take place. Much debate has centred on the properties of the EU as a normative power: How far norms adequately describe "who the EU is" (Forsberg, 2011; Manners, 2002), and whether normative power adequately describes key characteristics of EU foreign policy and the promotion of norms (Hyde-Price, 2006; Lucarelli \& Menotti, 2006; Tocci, 2008). An implicit and largely unquestioned assumption of these debates is that the EU has the inherent moral authority as a normative power to act upon its principles, including the possibility of using coercive actions, such as sanctions or military force, in the pursuit of normative goals. Yet, while the EU certainly possesses qualities of normative power as an international actor (e.g., Manners, 2006), a significant body of literature demonstrates that EU foreign policy is often based on the EU's own economic and geopolitical interests and the particularistic interests of its member states (e.g., Bosse, 2012; Ghazaryan, 2014; Pace, 2009), and that its normative role is increasingly contested in a transitional international order (e.g., Badescu, 2014; Newman, 2013; Newman \& Stefan, 2020), thereby calling into question the EU's intrinsic credentials as a legitimate authority to resort to unilateral coercive measures against third countries. Moreover, general international law remains ambiguous on the question of whether an IO, like the EU, can actually invoke international responsibility for the breach of a so-called erga omnes obligation, that is, an obligation in the general interest of the international community as a whole, as this obligation may only apply to states (Tzanakopoulos, 2013, 2015, pp. 156-157). 
Among the few scholarly works that do address the standards based on which the EU can assume the authority to act globally are those that examine the EU's sources of authority based on legal criteria, through the prism of EU law and the international legal order (e.g., Schmidt, 2020), or pre-defined sets of principles pertaining to community-based duties, rules, and outcomes/consequences that could serve as guidelines for a responsible role of the EU in global affairs (e.g., Mayer, 2008; Mayer \& Vogt, 2006).

The focus on legal rules, community-based duties, and consequentialist ethics provides key benchmarks for analysing the EU's authority to use sanctions against sovereign non-EU states unilaterally. However, the current literature misses two crucial aspects for determining the EU's authority: The first omission relates to the substance of the EU's authority. The current literature predominantly links sources of authority to ethical responsibilities towards fellow citizens, which can only arise from being part of an (artificial) political/legal community (cf. Mayer, 2008). As such, scholarly works operate with the assumption that the EU only resorts to countermeasures such as sanctions in cases where the EU itself is individually injured by a breach of international law committed by a third country or instances of intraEU sanctions. What is missing is an account of sources of moral authority, which considers that international actors (states or IOs) may act out of a sense of collectively agreed upon duty towards fellow human beings, a duty that is not conditional upon the values held by any particular community. These sources of authority are of immediate relevance to unilateral sanctions imposed in response to serious human rights violations, which constitute the majority of coercive measures taken by the EU so far. These sanctions are so-called "countermeasures in the general interest" based on obligations owed erga omnes, that is, to the international community as a whole. Considering that the legality of such measures remains a matter of significant controversy in general international law (Dawidowicz, 2017; Sicilianos, 2002; Tams, 2005), the lack of focus on the standards that may authorise the EU to resort to such measures is a critical oversight.

The second omission pertains to how the EU arrives at a judgement or decision on unilateral sanctions against third countries. Restrictive measures (sanctions) are a core tool of the EU's Common Foreign and Security Policy (CFSP), where strategic bargaining in pursuit of the member states' interests is considered the primary mode of decision-making (e.g., Dyson \& Konstadinides, 2013). However, decisions pertaining to ethical and moral questions - such as whether it is "right," "good," or justified for the EU to take unilateral coercive measures, especially with regards to the legally ambiguous and controversial obligations owed erga omnes-can hardly be reached through bargaining. In strategic bargaining, member states' economic and (geo-)political interests most likely overpower any deliberation on the "general interest" of the international community. However, a growing number of scholars have demonstrated that deliberation and argument do play a significant role in CFSP, including decisions on EU sanctions, which are often "pre-cooked" in deliberative CFSP committees (e.g., Breuer, 2012; Kurowska \& Kratochwil, 2012; Tonra, 2015). Committee discussions often include the Commission, which also prepares proposals for regulations on sanctions for adoption by the Council of the EU. In other words, the mode of decision-making at the EU level is critical with regards to the authority of the EU to resort to coercive measures such as sanctions against third countries, considering that a decision based on bargaining always represents particularistic member state interests (or a lowest common denominator) rather than a decision in the "general interest" of the international community.

Therefore, a critical source of the EU's moral authority to resort to unilateral sanctions against third countries pertains to the decision-making processes and whether due deliberation (rather than strategic bargaining) has prevailed in the search for the final decision on resorting to such coercive measures. Put differently, a theoretical framework is required that is able to determine whether the EU's decisions to resort to unilateral sanctions against non-EU states are primarily driven by deliberation geared towards acting in the general interest of the international community (cf. Barnett \& Finnemore, 2005 , pp. 172-173) or by the strategic cost-benefit calculations of EU member states. Habermas's theory of communicative action offers a valuable analytical point of departure to address this problem.

\section{Sources and Standards of EU Authority: A Communicative Action Perspective}

Although Habermas' theory of communicative action (1987/2006) was introduced to the discipline of international relations over a decade ago (Risse, 2000) and has even found application in studies on the legitimate use of force (e.g., Bjola, 2005), it has so far not been operationalised in the context of EU decisions pertaining to coercive measures such as sanctions, in order to define standards of EU moral authority.

Moral authority here is defined as a source of authority from which IOs, such as the EU, derive the legitimacy and ability to act. According to Barnett and Finnemore (2005, p. 172-173), IOs are "created to embody, serve or protect some widely shared set of principles" of the international community and "supposed to be more moral (ergo more authoritative) in battles with governments because they represent the community against self-seekers."

In my work on a critical theory perspective on EU normative performance (Bosse, 2017), I identified that two aspects of Habermas's work in particular are relevant for defining the standards of EU moral authority with regards to resorting to unilateral coercive measures. 
First, Habermas offers a comprehensive definition of ethical and moral sources of authority, differentiating between ethical reason (what is good for us as a community?) and moral reason (what is good for all involved?). This distinction helps to conceptualise the standards, or justifications, for resorting to unilateral sanctions that go beyond the obligations arising from injuries incurred by the $\mathrm{EU}$ (individually) as a community, but also obligations owed erga omnes - that is, to the international community as a whole. And second, Habermas elaborates a set of ideal-type procedural standards for taking legitimate decisions pertaining to the use of coercive measures (the responsibility of decision-makers to commit to the search for the "better argument"). These ideal-type procedural standards pertain to the notion of deliberative legitimacy. Deliberative legitimacy is understood as the "non-coerced commitment of an actor to obey a norm adopted based on criteria and rules reached through a process of communicative action" (Bjola, 2005, p. 279), based on which the points of contention between actors' justifications to use coercive measures can be ascertained and validated.

The following section explains each aspect of Habermas' work and, drawing on my earlier writings on EU normative performance, develops the parameters of the moral dimension of the EU's authority to resort to unilateral sanctions against third countries.

\subsection{Ethical and Moral Reason as Sources of Authority}

Habermas offers definitions of normative principles and sources of moral authority which transcend the narrow perspective of any particular individual or group. He differentiates between authority based on ethical reason and authority based on moral reason (Habermas, 1993, p. 2). Both types of reason operationalise different sources of authority.

According to Habermas, ethical reason recognises that actors act on the basis of social identities, including a particular conception of "us" and the values represented by a specific community (Habermas, 1993, pp. 11-12). Ethical obligations are "rooted in bonds of a pre-existing community, typically in family ties" (Habermas, 2015, p. 22). Habermas accepts that ethical obligations presuppose "political contexts of life, hence contexts that are legally organised" (Habermas, 2015, p. 24). Yet, he distances himself from the notion of "national solidarity" (responsibilities towards fellow-nationals and national community). For Habermas, "robust" ethical responsibilities towards fellow citizens can only arise from being part of an (artificial) political/legal community (civic solidarity) rather than from "organically" evolved nationhood (Habermas, 2015). The EU may thus justify its response to violent oppression and conflict in a country in its Eastern neighbourhood based on responsibilities toward members of the organic community of fellow Europeans or European countries, or fellow members of the (European) liberal democratic community.
Moral reason recognises that actors act on the basis of a (collectively agreed upon) duty towards fellow human beings, which operates independently of the values held by any particular community (Habermas, 1993, pp. 12-14). This type of reason relates to moral claims and duties arising from common human nature and responsibilities arising from our shared humanity (Habermas, 1993, pp. 68-69). According to Habermas (2015, p. 23), "moral commands should be obeyed out of respect for the underlying norm itself" (they have "categorical" force) without regard to the future compliance of other persons. Two main "duties" arise in the international arena: the duty not to engage in wars of aggression and not to commit crimes against humanity (responsibilities of sovereign states/passive responsibility). At the same time, Habermas foresees a collective responsibility of the international community to prevent war and enforce human rights (active responsibility). With regards to the standards for legitimate intervention and the authority to use coercive measures, Habermas prioritises that any form of intervention is legitimised by international courts or by a political decision of the United Nations (Security Council). However, unilateral coercive measures can also be regarded as legitimate through the tacit authorisation of the society of a world citizen's community, in "anticipation of the cosmopolitan order to come" (Habermas, 2015, p. 24). The EU may thus justify coercive measures against a third country with reference to the country's obligations as a sovereign state or with reference to obligations owed erga omnes to the international community as a whole.

From the discussion above, we can identify two main standards which lend the EU the moral authority to resort to unilateral sanctions against third countries: The EU commits not only to ethical reason (responsibilities for and between fellow Europeans or European civic/political community) but also moral reason (responsibilities for and between human beings in a global society) to justify such coercive measures.

\subsection{Authority Through Deliberative Legitimacy}

The standards for the authority of the EU to use unilateral sanctions against third countries can, however, not solely be derived from how the EU itself justifies such interventions. The EU's official rhetoric provides important clues on how the EU justifies such coercive measures vis-à-vis third countries, the wider international community, and towards EU citizens. But it reveals little about how the EU arrives at decisions to use unilateral sanctions, namely whether the actors involved in the decision-making process have tried to reach a "reasoned consensus" on the need for coercive measures, or whether such decisions were pushed by member states advocating the use of coercive measures which "just engage in power games" with no "visible intention to achieve argumentative consensus" on the intervention (Bjola, 2005, pp. 279-280). 
The concept of deliberative legitimacy is key to addressing this question.

According to Habermas, the processes pertaining to decisions on ethical and moral questions-whether it is "right," "good," or justified for the EU to resort to unilateral coercive measures against a third country-must be arrived at through dialogue and argumentation in a process of communicative action. To eventually agree on "the better argument," all parties involved must be able to present, justify, and defend their specific claims on "what is right." A vital prerequisite for such communication is that participants act (and recognise each other) as "persons capable of taking responsibility for their actions" (Habermas, 1993, p. 66). In other words, participants in decision-making processes share responsibility for committing to and ensuring a fair decisionmaking process. Habermas argues that the ideal speech situation, that is, the ideal process of fair communication, depends on three main standards (cf. Habermas, 2006, p. 185; see also Bjola, 2005, p. 280; Bosse, 2017; Head, 2008) which must be met for deliberative legitimacy to be achieved:

- Prior argumentation: Decisions on using coercive measures must be derived on the basis of truthful and complete facts, drawing on the best evidence and most compelling arguments available. Decisions are only accepted if they are justified.

- Inclusive processes: The communication and decision-making allow for the participation of all affected parties, who should have equal rights with regards to making or challenging an argument. Power games or coercion should not obstruct the deliberations.

- Genuine interest: Participating actors must display a genuine interest in argumentative reasoning and in finding a consensus (the "better argument") with regards to the use of coercive measures. Actors must be denied opportunities to resort to strategic manipulation or deception.

In Sections 3.1 and 3.2 above, the article outlined the main sources of and standards for the EU's moral authority to resort to unilateral coercive measures such as sanctions against non-EU states. The sources of the EU's authority pertain to the EU's justifications for resorting to unilateral coercive measures (invoking and acting upon ethical and specifically moral responsibility). In addition, three main standards for EU moral authority were outlined, based on the concept of deliberative legitimacy, which is applied to decision-making processes on EU coercive measures (recognising and acting upon the responsibility to agree on the better argument). The EU can only be considered to have the moral authority if it justifies sanctions based on ethical or moral reason and provided that all three standards of deliberative legitimacy are met. A form of partial authority can be considered if the first two standards are met because decisions on coercive measures are derived on the basis of facts and as complete evidence as possible, and from inclusive argumentation free from power games and coercion (cf. Bjola, 2005, p. 281).

\subsection{Case Study}

The analytical value of the standards of moral authority presented above will be assessed empirically in an illustrative case study of the EU's decision to use unilateral coercive measures in response to the massacre of civilians in the Uzbek town of Andijon following anti-government protests in May 2005. The case study is relevant because it is the first unilateral sanction regime imposed by the EU after the Council adopted the Basic Principles on the Use of Restrictive Measures (Sanctions) in 2004. The Basic Principles outline, for the first time, the EU's main principles guiding the imposition of sanctions by the EU in the absence of a UN Security Council mandate, including to "uphold respect for Human Rights, democracy, the rule of law and good governance" (Council of the European Union, 2004). The EU's decisions to impose, and subsequently lift, the sanctions against Uzbekistan mark the beginning of the EU's formal commitment to and systematic use of unilateral coercive measures based on a set of clearly defined principles. The Uzbekistan case is, therefore, a logical starting point for examining the EU's authority to impose unilateral coercive measures, opening a research line, and providing the theoretical framework for future comparative case studies analysing EU moral authority in the context of unilateral sanctions that the EU has imposed since it intervened in Uzbekistan. The case serves as a benchmark for the EU's capacity to learn and adjust decision-making on sanctions over time in view of meeting the relevant standards of authority. How far such adaptations have been made over the past decade is assessed in the concluding section. Finding data to conduct an analysis on the EU's sources and standards of moral authority is very demanding. The case study, therefore, draws on a variety of data sources which are triangulated to increase the validity of the findings (Flick, 2018), including primary data (EU official documents and 15 semi-structured interviews with EU officials and member state diplomats in Brussels conducted in 2006 and 2009), and secondary data (think tank reports and international news outlets).

\section{The EU's Response to the Uzbek Government's Brutal Crackdown on Opposition Protests in 2005}

On May 13, 2005, thousands of unarmed protesters took to the streets in Andijon, Uzbekistan, to demonstrate against poverty and government repression. Later that day, troops associated with the Uzbek government forces fired into a crowd, killing between 200 and 1,000 people. The EU reacted to the Andijon massacre by imposing unilateral coercive measures in November 
2005, including an arms embargo on the Uzbek regime and a visa ban on top Uzbek government officials directly responsible for the excessive, disproportionate, and indiscriminate use of force by Uzbek security forces in Andijan. In 2009, the EU decided not to prolong the sanctions against the Uzbek regime.

\subsection{Ethical and Moral Reason as Sources of EU Authority}

In the conclusions of its Council in November 2005, the EU justified its decision on the imposition of sanctions against the Uzbek regime, stating that it "deeply regrets the appalling loss of life and expresses its sympathy to the people, who have suffered as a consequence of violence" (Council Common Position 2005/792/CFSP of 14 November 2005, 2005, p. 15). The Council further detailed that it "strongly condemns the reported excessive, disproportionate and indiscriminate use of force by the Uzbek security forces and calls upon the Uzbek authorities to act with restraint in order to avoid further loss of life." (Council Common Position 2005/792/CFSP of 14 November 2005, 2005, p. 15). Further, the Council stated that it "calls upon the Uzbek authorities to respect their international commitments to democracy, the rule of law and human rights" and "recalls, in particular, the commitments and the existing mechanisms in the framework of the EU-Uzbekistan Partnership and Cooperation Agreement and in the OSCE [Organisation for Security and Cooperation in Europe]" and that it "urges the Uzbek authorities to carry out domestic reforms, which are essential for the social and economic development and the achievement of democracy and stability in the country" (Council Common Position 2005/792/CFSP of 14 November 2005, 2005, p. 15).

The EU thus justified the unilateral sanctions against Uzbekistan partly for moral and partly for ethical reasons. It highlighted the moral failure of the Uzbek government to protect human rights by deploring the excessive use of force by the government against civilians. Moreover, the EU explicitly expressed its "sympathy" to the Uzbek people and their suffering (Council Common Position 2005/792/CFSP of 14 November 2005, 2005, p. 15), which demonstrates that the EU recognised or at least implied that the Andijon massacre was a concern for the EU by virtue of its shared humanity with those who have experienced violence (moral obligations owed erga omnes). Yet, this recognition did not prompt the EU to spell out any specific duties or responsibilities vis-à-vis the Uzbek people. Rather, the statement focused on the EU's strong condemnation of the Uzbek government. The EU also projected duties on the Uzbek government pertaining to its (failed) obligations as a liberal democratic state (e.g., obligations to achieve democracy and to reform flowing from legal agreements with the EU and OSCE commitments). This implies that the EU implicitly recognised a shared ethical responsibility based on the assumption that Uzbekistan ought to adhere to the same standards as those countries comprising the European civic/political community.

\subsection{Deliberative Legitimacy as a Standard of EU Moral Authority}

Initially, EU member states were not able to find a consensus on the imposition of coercive measures (sanctions) against the Uzbek regime. On June 13, 2005, EU foreign ministers deplored that the Uzbek government had failed to accept an international investigation into the Andijon events. The EU reiterated its intention to partially suspend the Partnership and Cooperation Agreement should the Uzbek regime fail to meet the deadline to reconsider its position by the end of June 2005 . However, when it became clear that the Uzbek regime continued to refuse to allow an international investigation and when repressions against civil society increased even further, the EU did not suspend the Partnership and Cooperation Agreement and therefore failed to act on its earlier threat. Instead, the EU foreign ministers meeting on July 18 only decided to dispatch the EU's Special Representative for Central Asia to the region "as soon as possible" (Human Rights Watch, 2005; Leicht, 2005).

It took until November 2005 for the EU member states to reach a decision on the imposition of an arms embargo and restrictive measures (visa bans) against top Uzbek officials responsible for the excessive, disproportionate, and indiscriminate use of force by Uzbek security forces in Andijan in May 2005. The member states were under considerable pressure from human rights groups and domestic publics to find a consensus on sanctions against the Uzbek regime. Advocates of the sanctions, such as the UK government holding the EU presidency at the time, engaged in prior argumentation, drawing on the best evidence and most compelling arguments available. The UK government justified the imposition of sanctions based on reports prepared by Human Rights Watch, Amnesty International, and the OSCE. All available evidence, including personal accounts of Uzbek refugees who had fled following the violent crackdown (OSCE, 2005, p. 8), confirmed that the Uzbek security forces had indeed used "excessive, disproportionate and indiscriminate" force during the Andijon crackdown.

During the negotiations among the member states, the UK government not only presented the best evidence available from a wider range of sources but also allowed for an inclusive process. Among others, human rights NGOs and experts from think tanks and academia were invited to present statements and reports during the negotiations, and several member states also put pressure on the German government to refrain from insisting on its national strategic interests (interviews with EU officials and human rights NGOs in Brussels, 2006). At the time, Germany used the Termez base in Uzbekistan to support its military mission in Afghanistan and was keen to maintain the base and had grounded its argumentation mainly on strategic cost-benefit considerations 
(interviews with EU officials in Brussels, 2006; see also Borrut, 2009).

Eventually, the German government accepted the decision on the imposition of sanctions, though it remains unclear whether this decision was based on a genuine interest in argumentative reasoning and acceptance of the better argument. According to several EU officials, the German government may have only accepted the decision because it had managed to strike a deal with the Uzbek regime that would have allowed it to continue to use the Termez base even if the EU imposed sanctions (interviews with EU officials in Brussels, 2006). There are no alternative sources available to triangulate this claim. However, after the EU had imposed sanctions, the Uzbek regime notified several EU countries that they could no longer use Uzbek territory as a rear base for operations in Afghanistan, with the notable exception of Germany which received no such notification ("Germany seeks Uzbek base alternatives," 2005).

With regards to deliberative legitimacy, the authority of the EU to impose unilateral coercive measures on Uzbekistan can therefore be considered partial. The decision-making process was inclusive, and argumentation based on the best available facts, while it remains unclear to which extent the German government had a genuine interest in argumentative reasoning.

By contrast, the EU's decision to lift the sanctions in 2009 was not based on true and complete facts. The grounds upon which the EU had imposed the arms embargo against Uzbekistan (failure by the Uzbek authorities to respond adequately to the UN's call for an independent international inquiry into the Andijon events and the risk of internal repression) had remained unchanged. And even though the Uzbek government agreed to abolish the death penalty in 2008, the level of internal repression had further increased. In its October 2009 conclusions, the Council never provided an official basis for suspending the sanctions (Council of the European Union, 2009). During the meeting in October, the EU foreign ministers merely delivered a brief statement, stating that they wanted "to encourage the Uzbek authorities to take further substantive steps to improve the rule of law and the human rights situation...and taking into account their commitments, the Council decides not to renew the remaining restrictive measures" ("EU lifts Uzbek sanctions despite rights concerns," 2009). The statements' "truth-claims" are difficult to verify. The basis for lifting the sanctions is derived from the Uzbek government's (potential) future behaviour, rather than its actual (and observable) behaviour. At the same time, the justification diverts attention away from the main point of contention by implying that the sanctions were based on broader concerns about human rights and the rule of law (commitments that are more difficult to quantify) rather than the Andijon massacre and the level of internal repression. According to EU officials, the decision to suspend the sanctions "followed the release of several political prisoners and the abolition of the death sentence" (as cited in Castle, 2009, p. 1). This statement also shifts the focus away from the Andijon investigation and toward the Uzbek government's other, and exclusively positive, efforts and actions.

Some member states' main argument in favour of easing the sanctions, which was most prominently pushed by the German government, was that "the sanctions are not working and may be counter-productive" (Traynor, 2007, p. 1). This statement negates the very foundation of the arms embargo discussion. Rather than permitting a factual check on whether the Uzbek government had complied with EU demands, the statement turns the focus to a new question: whether the EU's sanctions are effective. The EU's and member states' statements in favour of lifting the embargo were thus attempting to avoid engaging in a truthful and factbased communication on whether the EU's demandsas explicitly stated in the first decision to impose the sanctions-had been met by the Uzbek government.

Likewise, the German government showed no genuine interest in argumentative reasoning and reaching a consensus on lifting the restrictive measures. Officials in the Council of Ministers' secretariat and several member states, including France, the UK, and the Scandinavian countries, had argued, based on the best available evidence, that the crackdown on dissent had not relented and that the EU should therefore get even tougher with the Uzbek regime (interviews with EU officials in Brussels, 2009; cf., Taylor, 2006; see also Spiller, 2006). However, instead of engaging in factful argumentative reasoning, the German government used its powers as a larger member state. It exploited the fact that a prolongation of sanctions would have required a unanimous decision by all member states to coerce other member states into accepting an end to the sanctions (interviews with EU officials in Brussels, 2009). The German government was not driven by concern over ethical or moral obligations towards the international community but rather its own strategic geopolitical interests. Aside from its strategic interests in the Termez base, Germany was about to assume the EU's presidency and was planning to launch the strategy for central Asia, with a focus on the security of energy supplies, and a key role for Uzbekistan, which has the second-largest gas reserves of the former Soviet states after Russia (Hall, 2007). Moreover, the Uzbek regime had been lobbying the German government very actively and successfully to get the sanctions overturned (Stroehlein, 2006).

\section{Conclusion}

This article set out to examine how far the EU meets the standards of moral authority that allow it to resort to unilateral coercive measures (sanctions) against non-EU states (third countries). It has been argued that little attention has so far been given to better understanding the sources of and standards for the EU's authority to resort to unilateral coercive measures such as sanctions, 
and, in particular, legally and politically controversial measures in reaction to violations of obligations erga omnes (obligations owed to the international community as a whole). When assessing the EU's moral authority, analysing dynamics within decision-making processes has been found crucial: It makes a difference if EU decisions have been determined by only the most powerful member states using bargaining, coercion, manipulation, or deception to enforce their strategic interests, or if decisions are derived from fact-based, inclusive, and non-coercive deliberations geared towards acting in the general interest of the international community.

To better capture the sources and standards of EU authority and to complement existing (legal) scholarship, the article developed the framework of the "moral dimension" of EU authority, drawing on Habermas's theory of communicative action. The framework maps a set of "ideal-type" standards of moral authority, namely the commitment to moral reason and the commitment to deliberative legitimacy, which help to assess whether the EU has the "appropriate moral credentials" (Linklater, 2007, p. 78), authorising it to resort to unilateral coercive actions such as sanctions abroad. Deliberative legitimacy, in particular, helps to assess how the EU arrives at decisions on such measures.

In the case study of the EU's decision to impose sanctions against Uzbekistan, the article empirically explored the framework's analytical contribution. The analysis revealed that the substantive and procedural standards of moral authority were partially satisfied. The EU justified the sanctions based on predominantly moral reason and obligations erga omnes, but it refrained from spelling out specific duties vis-à-vis the Uzbek people. And while the EU's decision to enact sanctions met two of the standards of deliberative legitimacy-accuracy of justifications and inclusive, deliberative processdoubts remain as to whether the most powerful member states had a genuine interest in argumentative reasoning, despite their consent to imposing the sanctions. The EU's decision to lift the sanctions in $\mathbf{2 0 0 9}$ met none of the standards of deliberative legitimacy. Evidence pertaining to ongoing and increasing human rights violations by the Uzbek regime was purposefully negated, rendering the EU's justifications for lifting the sanctions contradictory and inaccurate. By showing the analytical value of the framework of the "moral dimension" of authority, the article highlighted the potential of developing a broader research agenda for assessing how far the EU has the authority to resort to coercive measures such as sanctions against non-EU states in the absence of a UN Security Council mandate. As the EU's security and defence policy is integrating further, potentially leading to the launch of military operations without UN Security Council mandate in reaction to violations of obligations erga omnes, this research agenda will become even more relevant.

The case study also allows a broader reflection on the evolution of the EU's decision-making on sanctions since the early 2000s and implications for the standards of the EU's authority to resort to unilateral coercive measures. A first key development was the introduction of clearer guidelines on restrictive measures. However, while EU guidelines improved, EU decision-making on sanctions continued to be made "on the basis of assumptions" that had "not been sufficiently validated empirically" and lacked reliable data and data collection and processing (de Vries et al., 2014, p. 9). Recent examples of the EU imposing restrictive measures, such as the 2014 sanctions against the Russian Federation, demonstrate that additional resources were indeed allocated to improve data gathering and evaluation ahead of the decisionmaking (Fischer, 2015, p. 3). Yet, there are occasions on which little effort was made to collect robust and reliable data. The EU's decision in 2016 to lift sanctions against the authoritarian regime in Belarus, for example, was justified based on the (unvalidated) assumption that the human rights situation had improved. Robust evidence on increasing levels of human rights violations committed by Belarusian security forces was not sufficiently considered in the decision-making process, partly because of lacking or biased intelligence and partly because of strategic manipulation in pursuit of geopolitical interests (Bosse \& Vieira, 2018, pp. 18-19).

A second key development has been the improvement of the legality of the EU's restrictive measures and the extent to which they meet the requirements of fairness and due process (de Vries et al., 2014, p. 6). Since the early 2000s, the European Court of Justice has been reviewing the legality of restrictive measures against natural and legal persons, allowing them to challenge individual listings before the courts (Chachko, 2019, p. 13). While the European Court of Justice rulings have led to the annulment of hundreds of listings, they have forced the EU to better justify its decisions on restrictive measures and to provide more detailed reasons and supporting evidence for listing specific individuals (and entities) on its sanctions lists. The restrictive measures against Belarus imposed between 2020 and 2021 are good examples in that regard.

Over the past decades, the EU has thus taken steps to improve and expand evidence-based decision-making on unilateral sanctions. However, in respect to decisionmaking based on deliberation unobstructed by strategic bargaining and particularistic self-serving state interests, the EU still has some way to go before it fully meets the standards of moral authority which would endow it with legitimacy to resort to unilateral coercive measures.

\section{Acknowledgments}

This work was supported by the Netherlands Organization for Scientific Research (NWO) [Ref. 451-12-015].

\section{Conflict of Interests}

The author declares no conflict of interests. 


\section{References}

Badescu, C. G. (2014). The evolution of international responsibility: From responsibility to protect the responsibility while protecting. International Studies Journal, 11(1), 45-77.

Barnett, M. N., \& Finnemore, M. (2005). The power of liberal international organizations. In M. N. Barnett \& R. Duvall (Eds.), Power in global governance (pp. 161-184). Cambridge University Press.

Biersteker, T., \& Portela, C. (2015). EU sanctions in context: Three types (Briefing Paper No. 26). European Union Institute for Security Studies. https:// www.iss.europa.eu/content/eu-sanctions-contextthree-types

Bjola, C. (2005). Legitimating the use of force in international politics: A communicative action perspective. European Journal of International Relations, 11(2), 266-303.

Borrut, G. (2009, October 30). Questions arise over German role in ending Uzbek sanctions. Deutsche Welle. https://www.dw.com/en/questions-arise-overgerman-role-in-ending-uzbek-sanctions/a-4834212

Bosse, G. (2012). A partnership with dictatorship: Explaining the paradigm shift in European Union policy towards Belarus. Journal of Common Market Studies, 50(3), 367-384.

Bosse, G. (2017). EU normative performance: A critical theory perspective on the EU's response to the massacre in Andijon, Uzbekistan. East European Politics, 33(1), 56-71.

Bosse, G., \& Vieira, A. (2018). Human rights in Belarus: The EU's role since 2016. European Parliament's Subcommittee on Human Rights. https:// www.europarl.europa.eu/RegData/etudes/STUD/ 2018/603870/EXPO_STU(2018)603870_EN.pdf

Breuer, F. (2012). Sociological institutionalism, socialisation and the Brusselisation of CSDP. In X. Kurowska \& F. Breuer (Eds.), Explaining the EU's common security and defence policy: Theory in action (pp. 111-135). Palgrave Macmillan.

Brown, C. (2004). Do great powers have great responsibilities? Great powers and moral agency. Global Society, 18(1), 5-19.

Castle, S. (2009, October 27). Europe ends its attempt to penalize Uzbekistan. The New York Times. http://www.nytimes.com/2009/10/28/world/asia/ 28uzbek.html?_r=0

Chachko, E. (2019). Foreign affairs in court: Lessons from CJEU targeted sanctions jurisprudence. Yale Journal of International Law, 44(1). https://papers.ssrn.com/ sol3/papers.cfm?abstract_id=3157255

Council Common Position 2005/792/CFSP of 14 November 2005 concerning restrictive measures against Uzbekistan. (2005). Official Journal of the European Union, L 299/72.

Council of the European Union. (2004). Basic principles on the use of restrictive measures (sanctions). https://data.consilium.europa.eu/doc/document/ ST-10198-2004-REV-1/en/pdf

Council of the European Union. (2009, October 27). Council conclusions on Uzbekistan [Press release]. https://www.consilium.europa.eu/ueDocs/cms_ Data/docs/pressData/en/gena/110783.pdf

Dawidowicz, M. (2017). Third-party countermeasures in international law. Cambridge University Press.

de Vries, A. W., Portela, C., \& Guijarro-Usobiaga, B. (2014). Improving the effectiveness of sanctions: A checklist for the EU (CEPS Special Reports No. 95). Centre for European Policy Studies. https://www. ceps.eu/ceps-publications/improving-effectivenesssanctions-checklist-eu

Dyson, T., \& Konstadinides, T. (2013). European defence cooperation in EU law and IR theory. Palgrave Macmillan.

Erskine, T. (2004). "Blood on the UN's hands?" Assigning duties and apportioning blame to an intergovernmental organisation. Global Society, 18(1), 21-42.

Erskine, T. (2014). Coalitions of the willing and responsibilities to protect: Informal associations, enhanced capacities, and shared moral burdens. Ethics \& International Affairs, 28(1), 115-145.

EU lifts Uzbek sanctions despite rights concerns. (2009, October 27). Radio Free Europe/Radio Liberty. https://www.rferl.org/a/EU_Lifts_Uzbek_Sanctions_ Despite_Rights_Concerns/1862073.html

European Union Global Strategy. (2016). Shared vision, common action: A stronger Europe. A global strategy for the EU's foreign and security policy. https://eeas.europa.eu/archives/docs/top_stories/ pdf/eugs_review_web.pdf

Fischer, S. (2015). European Union sanctions against Russia: Objectives, impacts and next steps (SWP Comments No. 17). German Institute for International and Security Affairs.

Flick, U. (2018). Triangulation in data collection. In U. Flick (Ed.), The SAGE handbook of qualitative data collection (pp. 527-544). SAGE.

Forsberg, T. (2011). Normative power Europe, once again: A conceptual analysis of an ideal type. Journal of Common Market Studies, 49(6), 1183-1204.

Germany seeks Uzbek base alternatives. (2005, November 26). Deutsche Welle. https://www.dw.com/en/ germany-seeks-uzbek-base-alternatives/a-1792661

Ghazaryan, N. (2014). The European Neighbourhood Policy and the democratic values of the EU: A legal analysis. Hart Publishing.

Giumelli, F., Hoffmann, F., \& Książczaková, A. (2021). The when, what, where and why of European Union sanctions. European Security, 30(1), 1-23.

Habermas, J. (1993). Justification and application. MIT Press.

Habermas, J. (2006). The divided west. Polity.

Habermas, J. (2006). The theory of communicative action: The critique of functionalist reason (Vol. 2). Polity Press. (Original work published 1987) 
Habermas, J. (2015). The lure of technocracy. Polity. Hall, M. (2007). The EU and Uzbekistan: Where to go from here? (Policy Brief No. 138). Centre for European Policy Studies. https://www.ceps.eu/ceps-publications/ eu-and-uzbekistan-where-go-here

Head, N. (2008). Critical theory and its practices: Habermas, Kosovo and international relations. Politics, 28(3), 150-159.

Human Rights Watch. (2005). Burying the truth: Uzbekistan rewrites the story of the Andijan Massacre. https://www.hrw.org/report/2005/09/18/buryingtruth/uzbekistan-rewrites-story-andijan-massacre

Hyde-Price, A. (2006). "Normative" power Europe: A realist critique. Journal of European Public Policy, 13(2), 217-234.

Kurowska, X., \& Kratochwil, F. (2012). The social constructivist sensibility and CSDP research. In X. Kurowska \& F. Breuer (Eds.), Explaining the EU's common security and defence policy: Theory in action (pp. 86-110). Palgrave Macmillan.

Leicht, L. (2005, September 7). EU let Uzbekistan get away with murder. Politico. https://www.politico.eu/ article/eu-let-uzbekistan-get-away-with-murder

Linklater, A. (2007). Critical theory and world politics: Citizenship, sovereignty and humanity. Routledge.

Lucarelli, S., \& Menotti, R. (2006). The use of force as coercive intervention: The conflicting values of the European Union's external action. In S. Lucarelli \& I. Manners (Eds.), Values and principles in European Union foreign policy (pp. 147-163). Routledge.

Manners, I. (2002). Normative power Europe: A contradiction in terms? Journal of Common Market Studies, 40(2), 235-258.

Manners, I. (2006). Normative power Europe reconsidered: Beyond the crossroads. Journal of European Public Policy, 13(2), 182-199.

Mayer, H. (2008). The long legacy of Dorian Gray: Why the European Union needs to redefine its role in global affairs. European Integration, 30(1), 7-25.

Mayer, H., \& Vogt, H. (Eds.). (2006). A responsible Europe? Ethical foundations of EU external affairs. Springer.

Newman, E. (2013). R2P: Implications for world order. Global Responsibility to Protect, 5(3), 235-259.

Newman, E., \& Stefan, C. G. (2020). Normative power Europe? The EU's embrace of the responsibility to protect in a transitional international order. Journal of Common Market Studies, 58(2), 472-490.

Organisation for Security and Cooperation in Europe. (2005). Preliminary findings on the events in Andi- jan, Uzbekistan, 13 May 2005. https://www.osce. org/odihr/15653

Pace, M. (2009). Paradoxes and contradictions in EU democracy promotion in the Mediterranean: The limits of EU normative power. Democratization, 16(1), 39-58.

Risse, T. (2000). "Let's argue!": Communicative action in world politics. International Organization, 54(1), 1-39.

Schmidt, J. (2020). The European Union and the use of force. Brill.

Sicilianos, L. A. (2002). The classification of obligations and the multilateral dimension of the relations of international responsibility. European Journal of International Law, 13(5), 1127-1145.

Spiller, P. (2006, November 13). Europe's Uzbekistan dilemma. BBC. http://news.bbc.co.uk/2/hi/asiapacific/6136138.stm

Stroehlein, A. (2006). Uzbekistan: Beyond sanctions. International Crisis Group. https://www.crisisgroup. org/europe-central-asia/centralasia/uzbekistan/uzbekistan-beyond-sanctions

Tams, C. J. (2005). Enforcing obligations erga omnes in international law. Cambridge University Press.

Taylor, S. (2006, November 8). EU foreign ministers set to ease Uzbekistan sanctions. Politico. https://www.politico.eu/article/eu-foreignministers-set-to-ease-uzbekistan-sanctions

Tocci, N. (Ed.). (2008). Who is a normative foreign policy actor? Centre for European Policy Studies.

Tonra, B. (2015). Europeanization. In K. E. Jorgensen, A. K. Aarstad, E. Drieskens, K. Laatikainen, \& B. Tonra (Eds.), The SAGE handbook of European foreign policy (pp. 182-195). SAGE.

Traynor, I. (2007, May 14). Germany pushes for lifting of EU sanctions on Uzbekistan. The Guardian. http://www.theguardian.com/world/2007/may/14/ iantraynor.international

Tzanakopoulos, A. (2013). The countermeasure of disobedience: Implementing the responsibility of international organisations. In M. Ragazzi (Ed.), The responsibility of international organizations: Essays in memory of Sir lan Brownlie (pp. 161-172). Martinus Nijhof.

Tzanakopoulos, A. (2015). Sanctions imposed unilaterally by the European Union: Implications for the European Union's international responsibility. In A. Z. Marossi \& M. R. Bassett (Eds.), Economic sanctions under international law: Unilateralism, multilateralism, legitimacy, and consequences (pp. 145-161). T.M.C. Asser Press.

\section{About the Author}

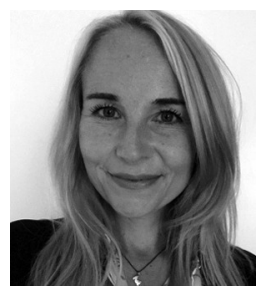

Giselle Bosse, PhD, is an associate professor in EU external relations, Jean Monnet chair in EU international relations, and vice dean at the Faculty of Arts and Social Sciences, Maastricht University. She is also co-director of the Centre for European Research in Maastricht and visiting professor at the College of Europe (Bruges). Bosse has been the principal investigator of several research projects on EU foreign policy and democracy and human rights promotion, inter alia funded by the Netherlands Organisation for Scientific Research (NWO). She has published extensively on EU relations with countries in the post-Soviet area and the EU Eastern Partnership. 